\title{
Ko wai au?
}

\section{Riki Paniora}

Riki Paniora of Te Roroa, Te Rarawa and Nga Puhi Nui Tonu descent is a senior lecturer on the Bachelor of Applied Social Work programme at Manukau Institute of Technology.

Ko wai au? He Tane au? He Papa au? He Tungane au? he tama o te atua au, Aye hei aha Ko wai au?

All of the above and more.

Who I am and what I am are two questions that have brought me to this point of reflection as I determine perhaps, what I am yet to become.

Cultural identity is important for people's sense of self and how they relate to others. A strong cultural identity can contribute to people's overall wellbeing (Ministry of Social Development, 2007).

Does culture play a significant role in my determination of who I am?

The purpose of this article is to take stock of who I am so as to understand what I may become. My journey has been filled with both positive and negative experiences, all of which have shaped me into the man that I am today. I wish to share some of what I believe are significant engagement points in my life that have made me the person and the professional that I consider myself to be. From my own myriad of pulsating life patterns, three key personal experiences display who I am.

\section{Experience one}

I come from a working class family, being the youngest of eight siblings. My parents were first generation off the farm, our papakainga, and into the big city. Poverty was an everyday occurrence as my father worked hard to provide for a large and young family. I remember the dinners that consisted of pipis takakau and cocoa.

Wairuatanga and hahitanga, spiritual matters and church played an important role for my family. My father passed away when I was young, which left my mother alone with a large family. Her spirituality became a central part of her life as it gave her the opportunity to be able to identify her beliefs and values, and, as all good parents do, pass them on to her children.

As I was the potiki of our whanau and my mother's constant companion, I seemed to have gotten both barrels of my mother's mana and was saturated by her beliefs. From this I have gained an in-depth understanding of wairua which still guides me today. I also learnt about the dynamics and practices associated with humility. Yet the greatest gift my mother gave me was a selfless capacity to love others.

When her ratbag kids didn't listen to her she turned her love to others and served in her church, greatly influencing those around her. She was well regarded and respected in the 
community. For my siblings and me it was a case of not fully understanding and appreciating what you have until it's gone. After my mother's passing much of this awareness of her true value emerged.

Oh how I miss those deep conversations and that endearing wisdom that I was exposed to, from my greatest teacher.

Moe mai, takoto mai, moe atu ki te kainga tuturu o tatou e taku nei whaea

\section{Experience two}

My parents realised the importance of education, and developed a desire for their children to become educated. My mother always used to tell me that if I took English, Maths, Geography and Engineering then I could get a job anywhere. As my older brothers and sisters had to leave school to go to work after my father passed away, education was not for them. My brothers just older than I flunked out at school, so I became the last hope to fulfil the desires of my mother.

I was preened to reach the fifth form and hopefully pass my School Certificate. I was able to achieve that goal and passed 'School C' in five subjects, almost unheard of in those days within our whanau. I then mucked around for the next two years trying to get University Entrance, which I finally did on the second attempt. Then I left school and went to work because university was not in my consciousness.

Upon reflection, I realised that my parents desired something better for their children. Education was the vehicle. Their desires were very simple as they understood it. What they were saying to my siblings and me was, 'Getting an education would get you a better job so that you could earn more money so that you wouldn't be poor like us'.

They looked to the horizon and saw something better for their offspring that wasn't available to them in their growing up. Unfortunately for me that horizon was their horizon, not mine. That is why I didn't carry on furthering my education. In a sense I floundered for the next 20 years in my quest for education.

I have since determined not to set horizons for my children, but to support them in any way that I can to develop their own horizons. That in itself is another experience that takes much listening and patience. I learned very quickly as my children grew up that what I thought was best for them was not necessarily what they believed was best for them.

My eldest daughter attended university, much to her father's delight. After a year she gave it up without a qualification, but with a $\$ 17,000$ student loan. Whilst she may have received value through this experience, it is yet to be realised.

My second daughter had doubts about tertiary studies and, learning from the first experience, I took a position of supporting her in the decisions that she made. This was very difficult because as parents we know what is right, or think we know what is right, for our children. It took patience and really listening to her. She finally found a path that was right for her. But that's not the end of it because the next year she was faced with the same 
dilemma. Well we got through it the first time, so the next time will be easier; at least that's what I kept telling myself.

My third daughter always knew what she wanted so supporting her was easy. I just needed to move a couple of mountains so she could attend university after deciding to go the day before university started. She is now on her journey, as all my children are. Education is not necessarily the pathway of choice, but as I look back I can see horizons. My children's horizons not mine.

The benefits of these experiences of horizon-setting did implant in me, way back then, a desire to carry on to university studies, as it's never too late to determine and achieve your goals. Twenty years later I fulfilled that moemoea partly because it was the right time and partly because it needed to occur, so I began my academic journey.

\section{Experience three}

I engaged in tertiary studies as a mature student and quickly became exposed to culture. I knew that I was Maori but I didn't have the reo. I felt Maori but didn't know the sign posts that located me within my culture. I guess I was who I was, and didn't really understand that there were certain markers that located me within a Maori paradigm, a valuable Maori perspective, and an in-depth Maori worldview. In reference to cultural identity, Wilson and Hunt (2000) make the following comment 'My right to be me, in my own way and in my own space includes the right to indigenous cultural rights'.

The first time I heard about the Treaty of Waitangi I remember crying, as I felt the impact of the presentation and an awareness of tangata whenua oppression. My tears turned to anger, anger towards the abuser 'the Pakeha'. I remember an incident on a bus where I couldn't get out from the back of the bus and the driver wouldn't open the door because he was not at a bus stop. I opened the door by pushing the emergency button and ranted as I jumped out.

Almost immediately I felt ashamed of what I had done. This is not me, I am not an angry person, my mother taught me to love and I didn't like the thing that I had become. I was determined to work through this issue and return to the person I was.

I was able to accomplish this by acquiring knowledge. I learnt all I could about Te Tiriti O Waitangi and colonisation. I realised the futility of rage against certain groups of people as I understood the nature of oppression by inherited systems within society and other such words as suppression, subjugation, etc. Those emotions were now harnessed to be utilised as motivation to bring about change and challenge the systems.

Freire (1972) defines the term 'conscientisation' or critical consciousness, where one can identify power dynamics and oppression through dialogical encounter with others. When I came to understand this, I realised the purpose of education is not to get a better job but to develop a critical mind, as it is the battles of the mind that break the shackles of poverty. Not poverty of the pocket necessarily, but poverty of the mind.

Academia has given me by far the greatest experiences in my recent journey. Experience one has given me the foundation of my beliefs and values, and experiences two and three 
have stabilised that foundation as I have critically assessed all of those beliefs and values I held to ensure that they were mine and not placed upon me by others. As a result some beliefs and values have been dropped, others have been added and valued ones have been reaffirmed.

The exciting aspect of this understanding and thinking is the realisation that the future holds so much more for us because of the yet unrealised potential that exists. Experiences in your life's journey can act as valuable building blocks if critically assessed as part of the learning process.

All of these experiences have left me affirmed in my mind as to who I am. Knowing who I am has allowed me to better communicate with others in my professional life. I am still shy and would rather sit at the back of the room and listen to others, but if I'm put in front of a class I will roar as a lion. The roar of passion in working with whanau and others and to engage in transformative processes as a change agent.

Ko wai au?

ROAR!!!

\section{Reference}

Freire. P. (1972). Pedagogy of the oppressed. Harmondsworth: Penguin.

Ministry of Social Development. (2007). DOI: http://www.socialreport.msd.govt.nz/cultural-identity/index. html 